\title{
Runoff Water in Cocoa Plantation as Affected by Rorak Number and Mulch Type
}

\author{
Sri Wahyuni ${ }^{1}$, Purwanto ${ }^{2)}$, and John Bako Baon ${ }^{\left.3^{*}\right)}$ \\ ${ }^{1}$ Directorate General of Estate Crops, Ministry of Agricuture of Indonesia, Jl. Harsono RM. No. 3, Ragunan, Jakarta \\ ${ }^{2}$ Faculty of Agriculture, Universitas Sebelas Maret, Surakarta, Indonesia \\ ${ }^{3)}$ Indonesia Coffee and Cocoa Research Institute, Jl. PB. Sudirman, Jember 68118, Indonesia \\ ${ }^{*}$ Corresponding author: jbbaon@gmail.com \\ Received: 19 November 2015 / accepted: 30 November 2015
}

\begin{abstract}
Soil erosion is a serious problem in the field of ecology and environment. Providing rorak (small blocked ditches) and mulches as an alternative conservation action is expected to minimize water runoff. The purpose of this study was to examine the effects of combination of rorak and mulches in controlling water runoff in a cocoa farm. Location of this research was in Kaliwining Experimental Station, Indonesian Coffee and Cocoa Research Institute during rainy season in early 2015. This research used a nested design in which there is a complete factorial design of random groups that every combination treatment was repeated three times. Each experiment plot consisted of 16 cocoa trees of eight years old. The first factor was rorak treatment consisted of without rorak, 9 rorak per 16 trees (plot) and 16 rorak per 16 trees, whereas the second factor was mulch treatment consisted of control (without mulch), cocoa leaves as mulch and rice straw mixed with cocoa leaves as mulch. Rorak collecting runoff water was made of aluminum with a length of $40 \mathrm{~cm}$, width $30 \mathrm{~cm}$ and high $30 \mathrm{~cm}$. Observation of runoff water was carried out early every morning. The results showed that increased number of rorak combined with cocoa leaf and rice straw significantly controlled runoff water compared to control. Rorak and mulch treatments were able to reduce runoff water compared to control. High number of rorak per plot increased the effectiveness in controlling runoff water when it was combined with mulch especially mixture of wide leaf (cocoa leaf) and needleshaped leaf (rice straw). Treatment of 16 rorak in every 16 trees with cocoa leaves and rice straw mulch could reduce runoff water by $82.8 \%$ compared to a control.
\end{abstract}

Keyword: mulch, rorak, ditch, runoff, cocoa, rice straw

\section{INTRODUCTION}

Cocoa development in Indonesia has been conducted since the end of $19^{\text {th }}$ century until now. Without rejuvenation, cocoa farms in Indonesia now have reached the age of 35 years old where their productivity have decreased. The decrease of national cocoa productivity is associated with the age of plant and reduction of soil fertility due to nutrient displacement and top soil loss which is rich in nutrients. By those three factors, the transported soil nutrient caused by surface runoff and erosion which is the biggest reason of nutrient loss have impacted on the reduction of soil fertility and plants productivity (Baon, 2012). An increase in the rate of erosion and surface runoff cause the most fertile top soil to be depleted, therefore it will reduce soil fertility.

One indicator of soil fertility level is its organic content which acts as a nutrient source, a nutrient binding agent and as 
substrates for soil microbes. Based on the work of Yusrial \& Kurnia (2006), along with the transported soil by runoff water, the soil organic content will decrease. Therefore, it needs an effort to control erosion through soil conservation. In the process of erosion, top soil which is rich in nutrients will be depleted. Surface runoff and soil erosion are the main causes of nutrients loss (Baon, 2014). By understanding the nutrients loss due to runoff water and erosion, the decrease of the soil fertility will be understood. One of the effort to overcome the problem of soil fertility reduction in cocoa plantation is by farm waste management which is by returning farm wastes into soil. The litter of farm wastes can be combined with local waste resources such as rice straw to be applied in cocoa farms.

Cocoa plantation generally derived from land conversion. According to Monde et al., (2008) the conversion of land into cocoa plantation will increase erosion and runoff water and therefore it is necessary to implement proper soil and water conservation by establishing rorak (blocked ditches) and mulch. Conservation techniques in cocoa plantation by using rorak can reduce the amount of soil erosion by $76 \%$ compared to control with no rorak (Monde et al., 2010). Application of mulch in amount of 6 tonnes/ha in cacao plantation at the age of 5 and 3 years old reduced the amount of surface runoff by $71 \%$ and erosion by $87 \%$.

The practice of soil conservation in form of rorak and mulch has already been applied, but there is not much data concerning their relationship on runoff water, sediment and nutrient loss as well as organic materials in cocoa plantation system especially in wet season (Mandal et al., 2012). This study examines the effect of combination between number of rorak and kind of mulchon the amount of surface runoff water in a cocoa plantation.

\section{MATERIALS AND METHODS}

Location for this study was in Kaliwining Experimental Station of Indonesian Coffee and Cocoa Research Institute (ICCRI), Rambipuji District, Jember. Topography of this study site was flat (4\%) at an altitude about $45 \mathrm{~m}$ asl. The field experiments as well as the observations was conducted for 8 weeks during rainy season from 19 February until 19 April 2015.

Based on Kaliwining Climatology Station data for the last 30 years and according to Schmidt and Ferguson classification, the rainfall type of Kaliwining experimental station was $\mathrm{D}$ with a $\mathrm{Q}$ value of $65.7 \%$. The soil type in Kaliwining experimental station belongs to Inceptisol. The soil texture in the experimental field consisted of $74.0 \%$ sand, $18.2 \%$ silt, and $8.2 \%$ clay, or texture of the soil classified as a loamy sand. Bulk density of the soil was about $0.9 \mathrm{~g} / \mathrm{cm}^{3}$, the particle density was $2.2 \mathrm{~g} / \mathrm{cm}^{3}$, while the porosity was $57.41 \%$.

Prior application of the treatment, Nitrogen (N) content of the soil was in the minimum threshold requirements for growing cocoa plants, while Phosporus (P) and Potassium $(\mathrm{K})$ were below the minimum threshold. The average level of C-organic at the time of the study was $0.9 \%$ which was below the minimum requirements of growing cocoa.

This study used a nested pattern design in which there was a complete randomized block design in factorial in which every treatment was replicated three times. The first factor was number of rorak, while the second factor was kind of mulch. Each experimental plot consisted of 16 cacao trees at the age of 8 years old with planting distance of $3 \mathrm{mx} 3 \mathrm{~m}$ the cocoa trees. The cocoa trees were grown under Leucaena leucocephala with planting distance of $3 \mathrm{~m} \times 3 \mathrm{~m}$. The first factor was number of rorak (length $40 \mathrm{~cm}$, width $30 \mathrm{~cm}$ and depth $30 \mathrm{~cm}$ ) and the second factor was kind of mulch. 
The first factor consisted of without rorak (R0), 9 rorak for every 16 trees (R9) and 16 rorak in every 16 trees (R16). The second factor consisted of without mulch (M0), cocoa leaves mulch in amount of $6 \mathrm{Mg} \mathrm{ha}^{-1}(\mathrm{Mk})$, and mix of cocoa leaves mulch and rice straw in amount of $3 \mathrm{Mg} \mathrm{ha}^{-1}$ and $5 \mathrm{Mg} \mathrm{ha}^{-1}(\mathrm{Mkj})$, respectively. In total there were 9 treatment combinations and every treatment had three replications. Each treatment plot was separated by silver black plastic sheet embedded into soil about $15-20 \mathrm{~cm}$ depth and $15-20 \mathrm{~cm}$ above the soil surface. The purpose of separating each plot was that each plot has to catch all the rains falled into that plot and to reduce the effect of other treatments.

Data of the amount of runoff waterwas obtained from a tool made from aluminium which was installed inside the rorak because the size of the tool was the same with the size of rorak. In the 9 rorak treatments, one tool was installed in every plot and placed in the rorak which is located in the middle. In the 16 rorak treatment, two tools were installed in every plot and placed in the middle with an unparallel position. The amount of water collected in rorak on each rainy day was measured based on its volume.

Rainfall data collection was based on primary and secondary data. Primary rainfall data was obtained from rain gauges installed outside and inside the canopy of cocoa trees, while secondary rainfall data was obtained from Kaliwining Climatology Station located about $100 \mathrm{~m}$ within the location of that Research Station. Daily observations were conducted by measuring the volume of runoff water. Effectiveness of rorak and mulch treatment was calculated based on the percentage of difference between total runoff water of treatment and control devided by that of control.

\section{RESULTS AND DISCUSSION}

Rain is one of main factors that caused surface runoff (runoff water) and erosion. The effects of rainfall on runoff water depend on duration, intensity and distribution of its area (Schwab et al., 1993). Rainfall intensity and land covering by vegetation play important roles in the process of runoff water (Zhang et al., 2011). High rainfall intensity have more impact on runoff water than on the erosion and sediment transport (Li et al., 2012).

Based on rainfall observations, since the first observation on 19 February until 19 April 2015, there were 40 rainy days in which 27 times were classified was heavy rain. Rainfall data at the study site (both outside and inside cocoa canopy) was compared with the data from Climatology Station as presented in Table 1. In the rainfall data outside cacao canopy, the plant had significant influence because closer distance to the trees compared to Climatology Station. Rainfall based on Climatology Station data was always higher than rainfall outside the canopy, meanwhile rainfall inside the canopy was tended to be lower than the rainfall outside the canopy. This may be due to interception that rainwater was restrained by plants or other surfaces and distributed to the ground (Kodoatie, 2012) or the rain water was collected through the surface of the canopy and branches (Asdak, 2004).

The rainfall pattern during this study period from February to April 2015 was generally similar. Rain with normal to heavy intensity often occured in early months and then begin to decrease the intensity up to light or very light and to increase again on the middle of the month. The research results of Zhang et al. (2011) showed that rainfall was one of the affecting main factors, where higher rain intensity accompanied by 
Table1. Rainfall according to Climatology Station data, outside and inside of canopy during the experiment (19 February19 April 2015)

\begin{tabular}{|c|c|c|c|c|c|c|}
\hline \multirow{2}{*}{ Block } & \multicolumn{2}{|c|}{ Climatology data } & \multicolumn{2}{|c|}{ Outside Canopy } & \multicolumn{2}{|c|}{ Inside Canopy } \\
\hline & $\mathrm{mm}$ & $\mathrm{m}^{3} / \mathrm{ha}$ & $\mathrm{mm}$ & $\mathrm{m}^{3} / \mathrm{ha}$ & $\mathrm{mm}$ & $\mathrm{m}^{3} / \mathrm{ha}$ \\
\hline I & $577 \pm 16,6$ & 5.775 & $436 \pm 11,9$ & 4.357 & $409 \pm 10,9$ & 4.087 \\
\hline II & - & & $410 \pm 10,8$ & 4.103 & $502 \pm 16,9$ & 5.020 \\
\hline III & - & & - & & $241 \pm 8,4$ & 2.413 \\
\hline Total & 577 & 5.775 & 846 & 8.460 & 1152 & 11.520 \\
\hline Mean & 14 & 144 & 11 & 106 & 10 & 96 \\
\hline
\end{tabular}

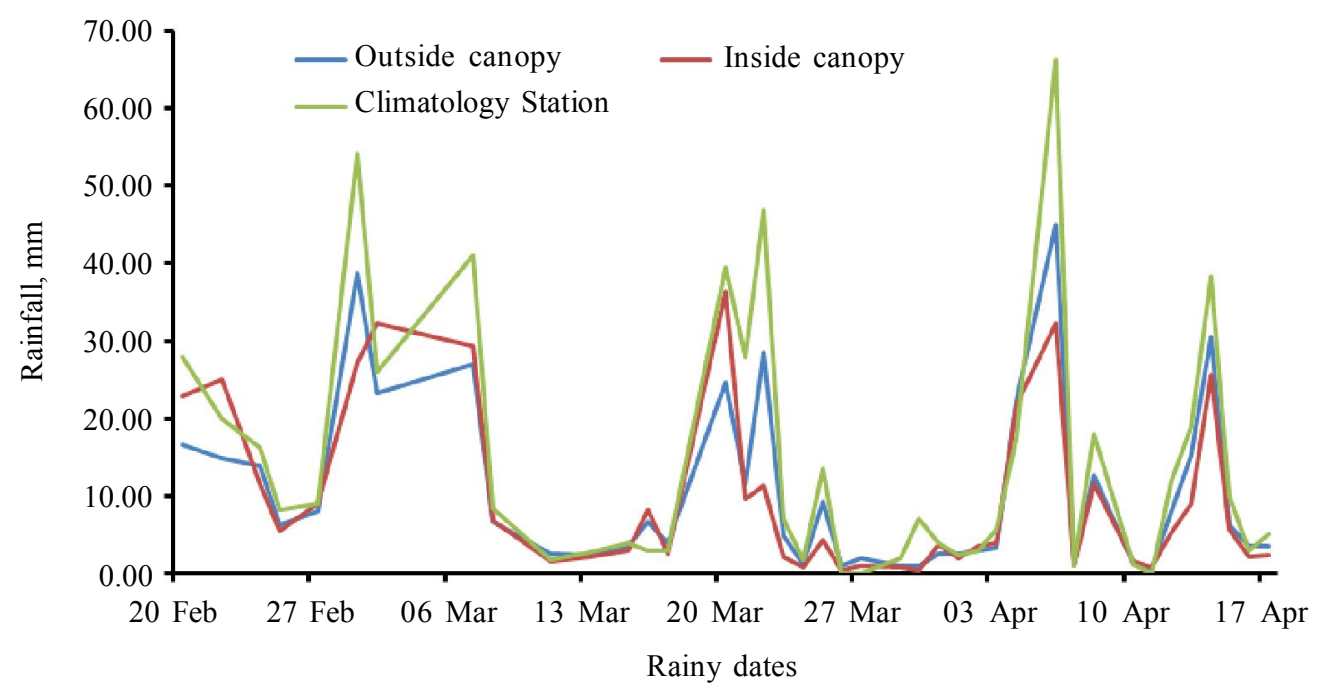

Figure 1. Distrbution of rainfall during period of research (19 February - 19 April 2015)

unfavorable land covering could produce higher runoff water.

Based on $F$ test, rainfall significantly $(p<0.05)$ affected runoff water. The same result was shown that when rained, rorak and mulch influenced the extend of runoff water significantly. Replications in form of blocks did not affect noticeable influence on runoff water. The amount of rainfall was positively correlated with runoff water $\left(0.499^{* *}\right)$.
Figure 2 shows that rorak treatment was able to reduce runoff water than no rorak treatment. In a combination with no mulch, 9 rorak in every plot could produce smaller runoff water than 16 rorak in every plot. However, in combination of mulch of cocoa leaves and rice straw, the amount of runoff water was smaller in the treatment with 16 rorak per plot. This results show that the many rorak was more effective in controlling runoff water when it was combined with mulch. 
Wahyuni et al.
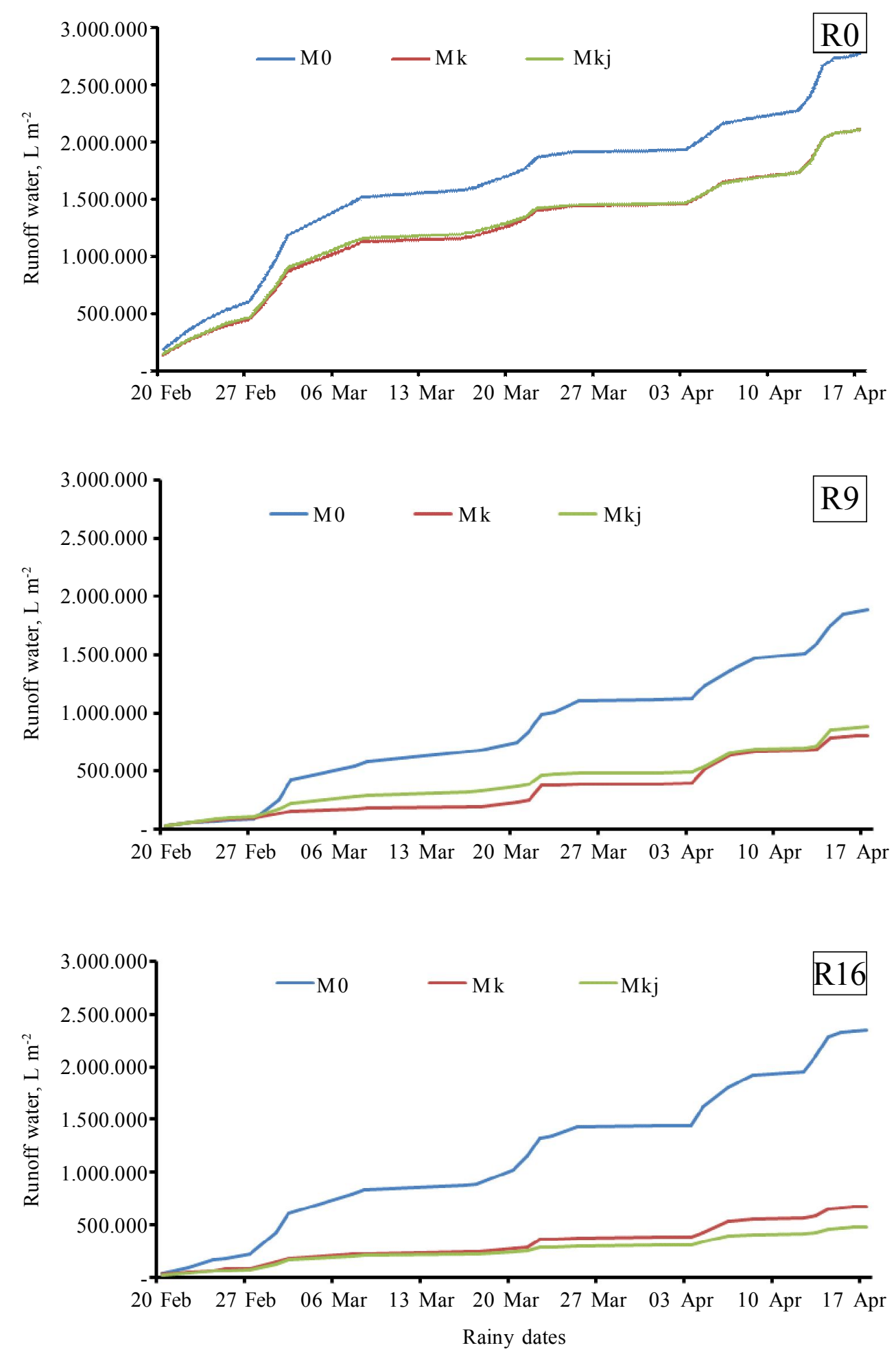

Figure 2. Development of accumulated runoff water during period of experiment as affected by rorak treatments, no rorak (R0), 9 rorak/16 trees/plot (F9), and 16 rorak/16 trees/plot (R16) 


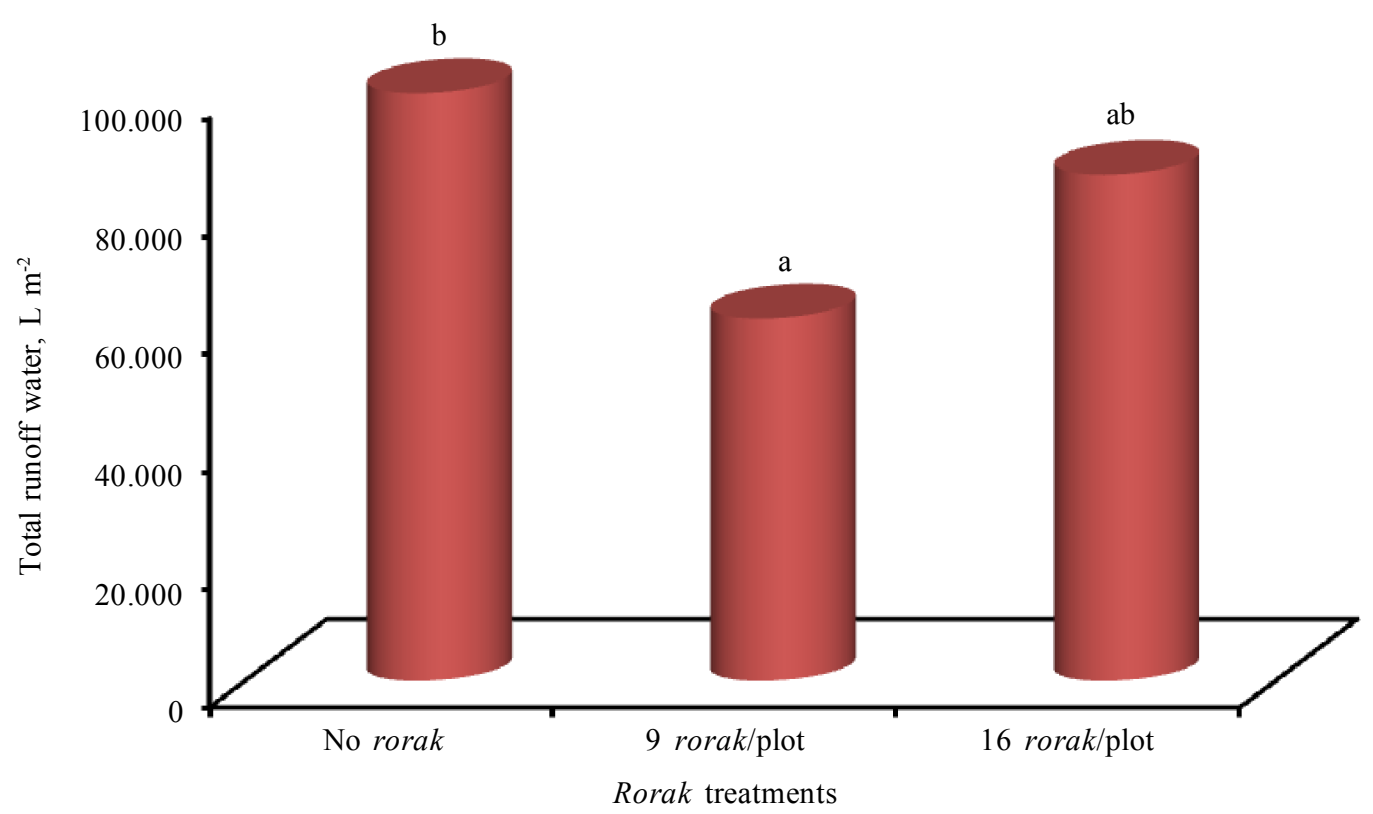

Figure 3. Effect of rorak (no rorak, $9 \mathrm{rorak} / \mathrm{plot}, 16 \mathrm{rorak} / \mathrm{plot}$ ) on total runoff water during experiment

Difference in rorak density affected the amount of runoff water (Figure 3). In reducing the amount of runoff water, 9 rorak treatment in every plot was lesser compared with application of a rorak without combination with mulch when rorak population was $50 \%$ of the cocoa trees.

In the treatment with no mulch, 9 rorak in every plot produced the smallest amount of runoff water compared to 16 rorak in every plot or a treatment with no rorak (Figure 4a). It shows that in the cocoa farm with no mulch, application of 9 rorak in every plot was better than 16 rorak per plot. Application of cocoa leaf as mulch combined with rorak was able to reduce runoff water. Combination of cocoa leaf mulch and treatment with 9 rorak per plot produced slightly higher amount of runoff water than 16 rorak in every plot, but it tended to be on the same level (Figure 4b). In the treatment combination of cocoa leaf and rice straw as mulch, 16 rorak per plot produced the smallest amount of runoff water (Figure 4c). The more variations of mulch types applied, the difference in runoff water between the treatment with no rorak with other rorak treatment on the same type of mulch was larger.

Treatment with no mulch on different rorak treatment generally produced higher amount of runoff water than mulch treatment on the same number of rorak. Application of mulch on soil surface has been claimed as an attempt to control erosion and to reduce evaporation (Rees et al., 2002). The use of mulch to cover soil ground may affect runoff water, however, the amount of runoff water itself is also influenced by rain intensity $(\mathrm{Li}$ et al., 2014).

It turns out that difference in mulch types which affecting runoff water was not significantly different although treatment with no mulch produced higher amount of runoff water than other mulch treatments. This study demonstrated that there was no interaction between type of mulch and runoff water (Figure 5). These results are similar with the study of Li et al. (2014) who stated that difference in leaf shape used as mulch 
Wahyuni et al.
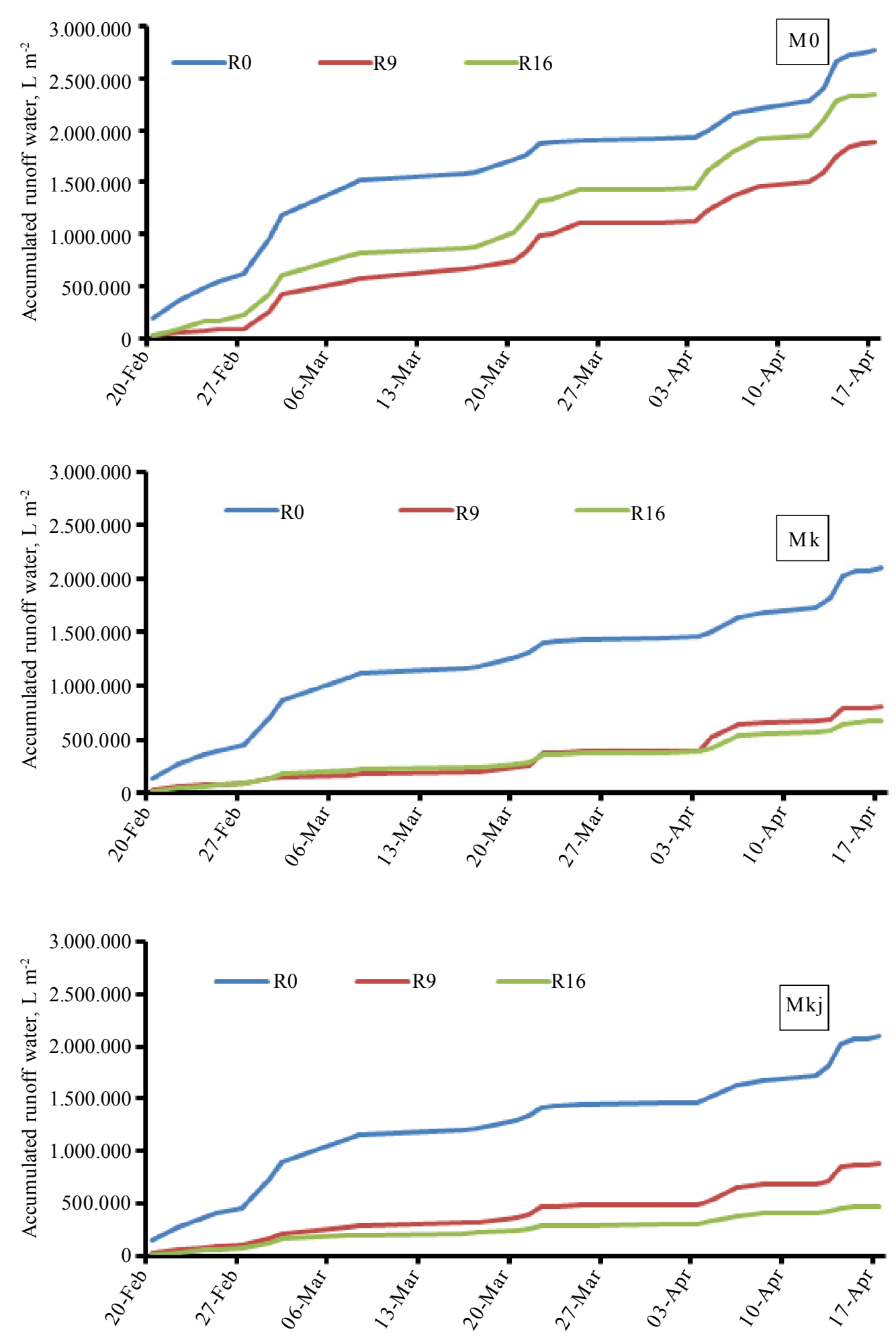

Rainy dates

Figure 4. Development of accumulated runoff water during period of experiment as affected by mulch treatment; no mulch (M0), cocoa leaves mulch (Mk), and cocoa leaves and rice straw mixture mulch 


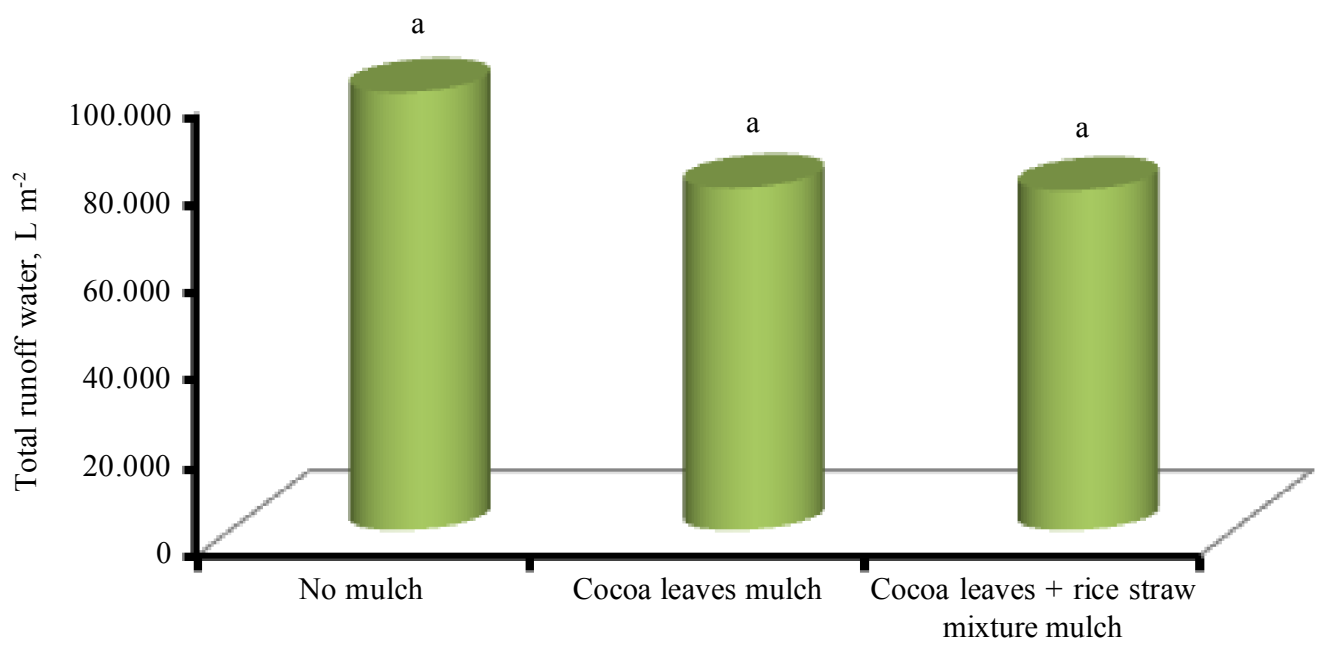

Mulch treatments

Figure 5. Effect of mulch treatments (no mulch, cocoa leaves, and cocoa leaves and rice straw mulch) on total runoff water

was not significantly different in controlling runoff water. Result of this research indicated that a treatment which used a combination of cocoa leaf mulch (wide leaf) and rice straw (needle-shaped leaf) produced small amount of runoff water compared with the treatment which only use cocoa leaf mulch.

Direction of water flow at experimental site was from north to south, while Block 3 was located in the most southern part on Block 1 and Block 2. It suggests that placement of blocks in this experiment was effective for rorak and mulch research. In general, there was noticeable difference between variations of runoff water and rainfall. Rain with very light intensity $(<5 \mathrm{~mm} /$ day $)$ was not significantly different from a rain with a light intensity $(5-20 \mathrm{~mm} /$ day). In the event of a rain on $1^{\text {st }}$ March 2015, according to climatological station, the rainfall was $54.1 \mathrm{~mm}$ or relatively heavy rain, while rainfall outside and inside canopy were 38.8 and $27.2 \mathrm{~mm}$, respectively, or classified as normal rain, although the volume of the runoff water was significantly different in general.
The volume of runoff water is directly proportional to rainfall. The higher the intensity of rainfall, the potential generated runoff water is also greater. The best rorak treatment to control runoff water was 9 rorak per plot compared to 16 rorakper plot and a treatment with no rorak as shown in Figure 7. A treatment with no rorak produced $\mathrm{R}^{2}$ value of 0.655 while the 9 rorakin every plot and 16 rorak in every plot produced respectively $\mathrm{R}^{2}$ values of 0.345 and 0.669 (Figure 8 ).

The best mulch treatment in controlling runoff water was cocoa leaves and rice straw combination which showed smaller coefficient of determination compared with cocoa leaf mulch and with no mulch as shown in Figure 9. The results showed that the most effective treatment in controlling surface runoff water was 16 rorak in every plot combined with cocoa leaf and rice straw mulch, while the treatment with 16 rorak in every plot with no mulch was the least effective treatment (Table 2). These results confirm with the research of Pratama \& 


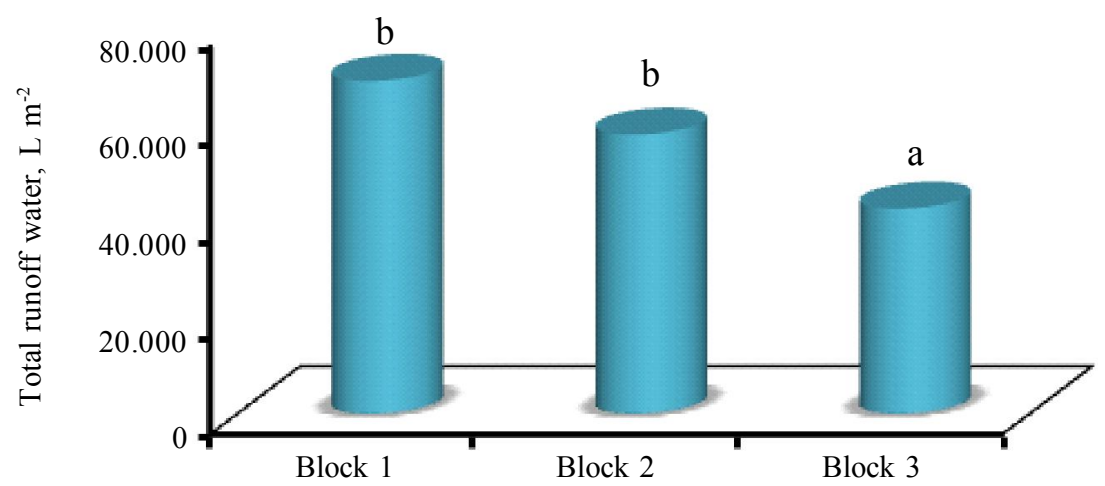

Gambar 6. Effect of block on total runoff water during the experiment.

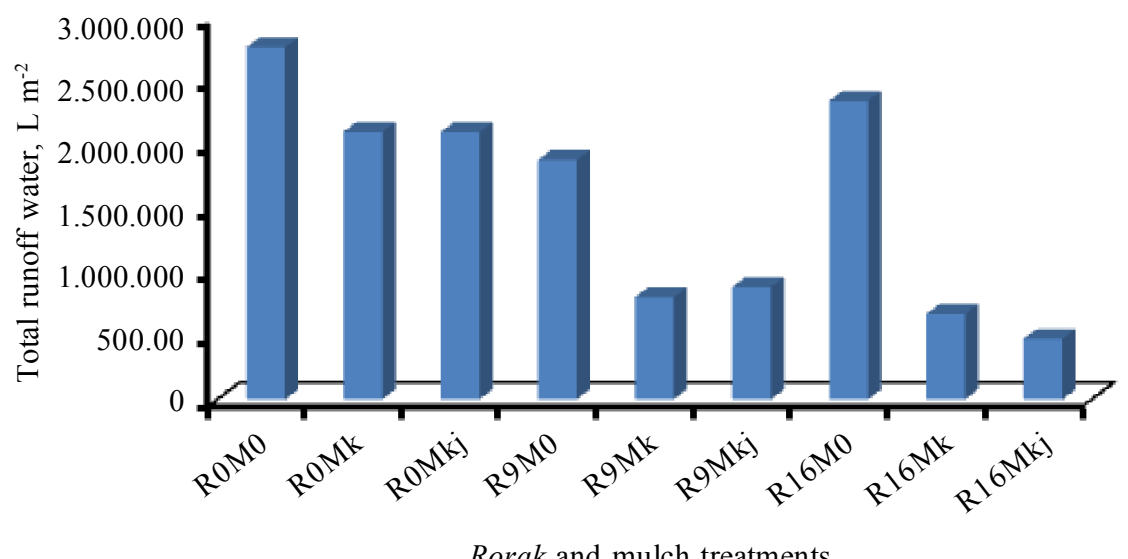

Figure 7. Effect of treatment combination of rorak and mulch on total runoff water during the experiment. 

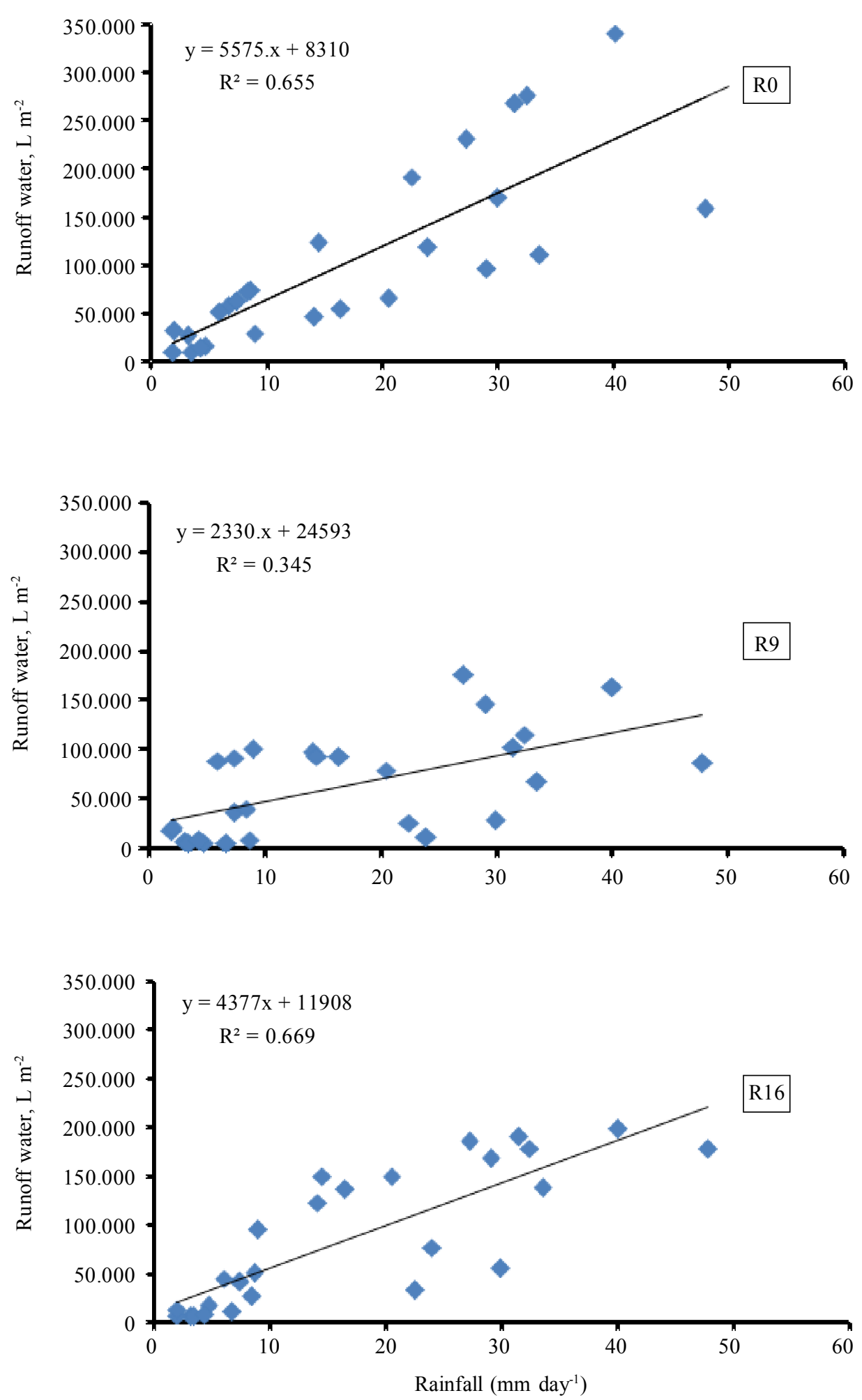

Figure 8. Relationship between rainfall and runoff water as affected by rorak treatments [no rorak (R0), $9 \mathrm{rorak} / \mathrm{plot}(\mathrm{R} 9)$, and $16 \mathrm{rorak} / \mathrm{plot}$ (R16)] 
Wahyuni et al.

Table 2. Effectiveness of rorak and mulch treatments based on volume of total runoff water

\begin{tabular}{lllcc}
\hline & \multicolumn{2}{c}{ Treatments } & & \multicolumn{2}{c}{ Runoff water } \\
\hline Rorak & \multicolumn{1}{c}{ Mulch } & Code & $\left(\mathrm{L} \mathrm{m}^{-2}\right)$ & Effectiveness, \% \\
\cline { 4 - 5 } No & No & & 2.770 .694 & $0,00 \mathrm{c}$ \\
No & Cocoa leaves (CL) & R0M0 & 2.104 .948 & $24,03 \mathrm{bc}$ \\
No & CL + straw & R0Mk & 2.103 .906 & $24,07 \mathrm{bc}$ \\
9/plot & No & R0Mkj & 1.884 .005 & $32,00 \mathrm{bc}$ \\
9/plot & $\mathrm{CL}$ & R9M0 & 804.538 & $70,96 \mathrm{~b}$ \\
9/plot & $\mathrm{CL}+$ straw & R9Mk & 883.910 & $68,10 \mathrm{a}$ \\
16/plot & No & R9Mkj & 2.350 .274 & $15,17 \mathrm{a}$ \\
16/plot & $\mathrm{CL}$ & R16M0 & 672.280 & $75,74 \mathrm{a}$ \\
16/plot & $\mathrm{CL}+$ straw & R16Mk & 477.110 & $82,78 \mathrm{a}$ \\
\hline Notes: Figures in the same column followed by the same letters are not significantly different according to Duncan MRT (5\%).
\end{tabular}

Salim (2013) who stated that a rorak treatment with a distance of 5 meters was able to decrease surface runoff and erosion by $2.1 \%$ and $13.6 \%$ compared with control plot.

Work of Zhang et al. (2010) showed that land covering significantly reduced the amount of runoff water and erosion. Rice straw mulch can be used for any type of soil and plants. Besides, it can be obtained easily where 5 tons of rice straw contained 2 tons of C-organic. If the rice straw is applied into the soil, the organic content and $\mathrm{K}$ nutrient will increase (Triyono, 2005).

This study was implemented on relatively flat area which is might be slightly eroded before. On that flat surface area there are possibly many very small sites where water accumulate, from there water may flow along furrows following the land slopes to lower area. The water furrow which may bring along soil is called riil erosion (Hakim et al., 1986).

Rorak application in between two cocoa trees combined with litter, cocoa leaf and rice straw as mulch, needs to be implemented in cocoa plantations, especially in smalholder farms which dominated more than $90 \%$ of national cocoa plantations. This technique can be performed from flat until sloping areas. Based on the results of a research in Ibadan-Nigeria, mulch material with the same amount and type when it is used to control erosion and runoff water in a land with slope until $20 \%$ showed not significant different result (Kartasapoetra, 2010).

\section{CONCLUSION}

Rorak and mulch treatments are able to reduce runoff water compared to control. High number of rorak per plot increase the effectiveness in controlling runoff water when it is combined with mulch especially mixture of wide leaf (cocoa leaf) and needleshaped leaf (rice straw). Treatment of 16 rorak in every 16 trees with cocoa leaves and rice straw mulch can reduce runoff water by $82.8 \%$ compared to a control.

\section{ACKNOWLEDGEMENT}

The authors would like to thank the Ministry of Technology and Research and Higher Education for supporting research funding from the program of Science and Technology Centre of Excellence provided through Indonesian Coffee and Cocoa Research Institute (ICCRI). The same gratitude for the staffs of the Soil and Water Sciences Laboratory of ICCRI and Laboratory of Chemistry and Soil Fertility of UNS which help a lot in this research. 


\section{REFERENCES}

Asdak, C. (2002). Hidrologi dan Pengelolaan Daerah Aliran Sungai. Gadjah Mada University Press, Yogyakarta.

Baon, J.B. (2012). Optimasi daur hara di kebun kakao untuk keberlanjutan produksi. pp. 138-147. In: Prosiding Simposium Kakao 2012. Padang., Sumbar: 5-8 November 2012. Pusat Penelitian Kopi dan Kakao Indonesia, Jember.

Baon, J.B. (2013). Renovasi kesuburan tanah lahan Kakao. Cokelat, OktoberDesember 2013, 4-6.

Hakim, N.; Y.M. Nyakpa; A.M. Lubis; S.G. Nugroho; M.A. Diha; G.B. Hong \& H.H. Bailey (1986). Dasar-dasar Ilmu Tanah. Universitas Andalas, Padang.

Kartasapoetra, A.G. (2010). Teknologi Konservasi Tanah dan Air. Rineka Cipta, Jakarta.

Kodoatie, R.J. (2012). Tata Ruang Air Tanah. Andi Offset, Yogyakarta.

Li, X.; J. Niu; J. Li; B. Xie; Y. Han; J. Tan \& Y. Zhang (2012). Characteristics of runoff and sediment generation of forest vegetation on a hill slope by use of artificial rainfall apparatus. Journal of Forestry Research, 23, 419-424.

Li, X.; J. Niu \& B. Xie (2014). The effect of leaf litter cover on surface runoff and soil erosion in Northern China. PloS ONE 9(9): e107789.

Mandal, U.K.; K.L. Sharma; J.V.N.S. Prasad; B.S. Reddy; B. Narsimlu; U.S. Saikia; R.V. Adake; P. Yadaiah; R.N. Masane; K. Venkanna; K. Venkatravamma; B. Satyam; B. Raju \& N.N. Srivastava (2012). Nutrient losses by runoff and sediment from an agricultural field in semi-arid tropical India. Indian Journal Dryland Agriculture Research \& Development, 27, 01-09.
Mengel, K. \& E.A. Kirkby (1978). Principles of Plant Nutrition. International Potash Institute, Switzerland.

Monde, A.; N. Sinukaban; K. Murtilaksono \& N.H. Pandjaitan (2008). Dinamika kualitas tanah, erosi dan pendapatan petani akibat alih guna lahan hutan menjadi lahan kakao di DAS Nopu, Sulawesi Tengah. Forum Pascasarjana $I P B, 31,215-225$.

Monde, A. (2010). Pengendalian aliran permukaan dan erosi pada lahan berbasis kakao di DAS Gumbasa, Sulawesi Tengah. Media Litbang Sulawesi Tengah, 3, 131-136.

Pratiwi \& A.G. Salim (2013). Aplikasi teknik konservasi tanah dengan sistem rorak pada tanaman Gmelina (Gmelina arborea Roxb.) di KHDTK Carita, Banten. Jurnal Penelitian Hutan dan Konservasi Alam, 10, 273-282.

Triyono, K. (2005). Pengaruh Sistem Pengolahan Tanah dan Mulsa Terhadap Konservasi Sumber Daya Tanah. Tesis. Program Studi Ilmu Lingkungan UNS.

Yusrial \& U. Kurnia (2006). Potensi erosi pada berbagai kelerengan sistem: usahatani lahan tegalan dan kebun rambutan di DAS Kali Garang. Prosiding Seminar Nasional Sumberdaya Lahan Pertanian. Balai Besar Penelitian dan Pengembangan Sumberdaya Lahan Pertanian. Badan Penelitian dan Pengembangan Pertanian. Departemen Pertanian. Jakarta.

Zhang GH.; G.B. Liu; G.L. Wang \& Y.X. Wang (2011). Effect of vegetation cover and rainfall intensity on sediment-associated nitrogen and phosphorus losses and particle size composition on the loess plateau. Journal of Soil and Water Conservation, 66, 192-200. 